\title{
PERAN FORUM PEMUDA KERUKUNAN UMAT BERAGAMA DAERAH ISTIMEWA YOGYAKARTA DALAM MEMPERKUAT PARADIGMA INKLUSIF KAUM MUDA
}

\author{
Makhrus \\ Universitas Muhammadiyah Purwokerto \\ Email: makhrus.ahmadi@gmail.com
}

\begin{abstract}
Religious life in Yogyakarta (DIY) has its own style and culture. It is based on the existence of DIY as a student town, travel, and education, resulting in DIY is seen as civil of tolerance due to DIY into a meeting place for differences of race, culture and religion. Thus, the existence of this study want to study on the role, community leaders and the government's response to the Youth Forum for Religious Harmony Special Region of Yogyakarta (FPKUB DIY) in strengthening the inclusive paradigm among young people in Yogyakarta.

This study used descriptive qualitative approach. While data collection techniques using the documentation, observation and interviews. Analysis of the data used in this research is data obtained and presented descriptively, begins by describing that has been expressed by the respondents either in person, in writing or direct observation. The process of data analysis is done by starting to examine all the data collected from various sources that had been predetermined.

This study shows that DIY FPKUB role in strengthening the inclusive paradigm of youth done with emphasis on inter-religious dialogue and national harmony. Form of program activities carried out by FPKUB DIY using participatory-dialogical that program activities runs are varied and well targeted, it is shown by the responses of participants who stated that $25 \%$ strongly agree, $60 \%$ agree, $15 \%$ disagree, $0 \%$ no agree, while the expectations of participants towards FPKUB DIY activities are in accordance with the expectations and desires of the participants with the response indicated 5\% strongly agree, $85 \%$ agree, $10 \%$ disagree, $0 \%$ disagreed. Response to the role of community leaders FPKUB DIY done by inserting a board representative FPKUB DIY into management FKUB DIY that became the highest forum forum
\end{abstract}


inter-religious harmony that already exist in each district and town in the province. Moreover, historically the birth of an initiative FPKUB DIY community leaders to encourage their mutual awareness among young people about religious harmony, so hope the presence of a pilot program DIY FPKUB other regions in Indonesia regarding inter-religious harmony forum based youth. The government's role Yogyakarta Special Region in strengthening the paradigm of inclusive youth conducted by FPKUB DIY done by providing facilities and infrastructures for use in a variety of activities by FPKUB DIY, though related forms penyelediaan facilities on grants and funding programs could not be implemented due to the lack of legal protection FPKUB overshadow the existence of DIY.

Keywords: paradigm, inclusive, youth, religious groups

\section{A. Pendahuluan}

Kehidupan berbangsa dan bernegara berkaitan dengan relasi masyarakat. Keterikatan tersebut tertuang dalam bentuk relasi tatanan kehidupan yang termanifestasi dalam bentuk aturan dan hukum yang berlaku ataupun pemahaman keagamaan yang dianut komunitas masyarakat tersebut, sehingga mampu membangun paradigma inklusif yang saling mengikat satu sama lain. Bentuk keteraturan tersebut pada akhirnya akan melahirkan persamaan visi dan pandangan bersama untuk saling menjaga suasana perdamaian, tanpa saling mendiskreditkan agama atau aliran keagamaan tertentu yang paling benar, meski tafsir mengenai Tuhan itu seluruhnya merupakan bagian dari kemampuan manusia itu sendiri ${ }^{1}$. Sementara perdamaian yang teratur dalam kehidupan antar umat beragama, harus diikuti oleh perdamaian dan keteraturan dalam kehidupan intra beragama. Sebab, ragam persoalan yang bermuara pada konflik atas nama agama, biasanya tidak hanya melibatkan antar umat beragama, melainkan juga melanda intra umat beragama, yang ditandai dengan diskriminasi terhadap perbedaan mazhab (aliran) keagamaan tertentu yang tidak sama dengan mayoritas mazhab agama tersebut, sehingga pada akhirnya menjadi bara konflik yang bisa meledak kapanpun dan dimanapun, bahkan pada tahap yang lebih ekstrim menjadi warisan konflik pada generasi yang berikutnya. Penyelesaian konflik yang bersifat generatif ini biasanya akan menjadi konflik laten yang agak sulit untuk dipadamkan.

Menurut UNESCO bentuk diskriminasi dan intoleransi agama, setidaknya dapat terlihat dalam sebagai berikut: membuat stereotipe, menyindir, prasangka, pengkambing hitaman, diskriminasi, pengasingan, pelecehan, penajisan dan penghapusan, penyusiran, pengeluraran, segregasi, represi, dan penghancuran. ${ }^{2}$ Sehingga konflik horisontal, baik intra atau antar umat beragama yang mengarah pada konflik laten yang dikarenakan adanya klaim tunggal kebenaran dan heroisme intra atau antar kelompok yang mengabaikan pihak lain harus diselesaikan secara

1 Moeslim Abdurrahman, 2005, Islam Yang Memihak, LKiS, Yogyakarta, hlm. 104.

2 Febi Yonesta, dkk., 2012, Memupuk Harmoni Membangun Kesetaraan Inisiatif Paralegal LBH Jakarta dalam monitoring Praktik Intoleransi dan Diskriminasi Berbasis Agama di Wilayah Jabodetabek, LBH Jakarta, Jakarta, hlm. 23-24. 
bersama. Maka, hadirnya peran dialogis diantara kalangan intra atau antar umat beragama harus menjadi media yang perlu dibina guna menemukan banyak ruang saling memahami satu sama lain. Hal tersebut diatas dapat dilakukan dengan menamkan benih kesadaran, pemahaman dan pengamalan tentang kerukunan umat beragama berbasis kaum muda. dikarenakan generasi muda merupakan generasi masa depan masyarakat dan bangsa yang harmoni tanpa ada konflik membelengg serta memiliki persamaan persepsi, pemahaman dan visi yang sama dalam jangka waktu panjang. Setidaknya, hal tersebut dapat mengacu pada elemen pokok hak kebebasan umat beragama dan berkeyakinan yakni: hak internal, hak eksternal, tidak ada paksaan, tidak diskriminatif, hak dari orang tua dan wali, kebebasan lembaga dan status legal, pembatasan yang diijinkan, dan tidak dapat dikurangi kebebasan beragama dalam keadaan apa pun. ${ }^{3}$

Keberadaan Daerah Istimewa Yogyakarta (DIY) sebagai kota pelajar, budaya dan pariwisata menyimpan beragam keistimewaan baik secara etnis, budaya ataupun agama, oleh karena itu, DIY disebut sebagai city of tolerance. Dalam kontek kehidupan keberagamaan, posisi agama bisa dihayati sebagai semangat dialog vertikal dan horisontal. Dialog vertikal ini akan menghasilkan kehidupan yang suci, indah dan jauh dari kesengsaraan, sedangkan dialog horisontal mengciptakan ketertiban, keserasian, perdamaian, kerjasama dan sebagainya. ${ }^{4}$ Jika ditinjau dari corak kehidupan keberagamaan, DIY sebagai daerah cukup plural dan multietnis, maka kehidupan keberagamaannya cenderung lebih kondusif dan mampu meminimalisir kekerasan atas nama agama atau aliran tertentu, sehingga corak keagamaannya dapat menjadi corak keagamaan yang bisa menjadi rujukan dari daerah lain sebagai kota yang toleran.

Proses toleransi di DIY yang awalnya berjalan secara kondusif secara perlahan mengalami pergeseran bersamaan dengan semakin melebarnya pintu dialog antarumat beragama. Berdasarkan laporan Aliansi Nasional Bhinneka Tunggal Ika kasus intoleransi di Yogyakarta mulai terjadi sejak tahun 2011 dan semakin meningkat setiap tahunnya. Hal tersebut ditandai dengan penutupan tempat ibadah, pelarangan aktivitas, ibadah, tidak dikeluarkannya ijin mendirikan tempat ibadah, larangan diskusi di kampus, hingga penutupan pondok waria, bahkan pada tahun 2015 saja sudah terdapat 15 tindakan intoleransi, hingga menyebabkan Kabupaten Sleman menjadi daerah yang paling banyak melakukan tindakan intoleransi ${ }^{5}$. Sumber lain yang menerangkan adanya tindakan intoleransi antar umat beragama dilakukan oleh Lembaga Bantuan Hukum Yogyakarta. Berdasarkan laporan Lembaga Bantuan Hukum Yogyakarta memiliki sepanjang rentang tahun 2011-2015 terdapat 13 kasus pelanggaran atas hak kebebasan beragama dan berkeyakinan yang meliputi katagori diskriminasi perizinan kegiatan keagamaan, perijinan pendirian rumah ibadah, tuduhan saling menyesatkan, pembiaran kelompok intoleran, serta penyebaran ujaran kebencian melalui media sosial, sehingga menurut pandangan Lembaga

3 Nurkholis Hidayat, Muhamad Isnur, Febi Yonista, 2011, Peradilan Kasus Kasus Kebebasan Beragama dan Berkeyakinan Rangkuman 8 Studi Kasus: Dampak, Capaian, Hambatan dan Strategi, LBH Jakarta, Jakarta, hlm. 20-21.

4 Latifatul Izzah el Mahdi, "Dialog Aksi Antarumat Beragama: Straregi Membangun Perdamaian dan Kesejahteraan Bangsa”, Jurnal Harmoni. Vol. VIII. No. 30 (April-Juni 2009) hlm. 29.

5https://nasional.tempo.co/read/news/2016/03/11/173752571/kasus-intoleransi-di-yogyakarta-tinggi diakses 09/05/2016 waktu 15.45 
Bantuan Hukum Yogyakarta daerah Yogyakarta masih mengalami darurat intoleransi ${ }^{6}$.

Sikap intoleransi yang terjadi di DIY dapat diminimalisir dengan terus mendorong sikap toleransi di masyarakat. Sikap toleransi menjadi keniscayaan dalam merajut hubungan antar umat beragama sebab hubungan antar umat beragama selalu faktual sepanjang sejarah umat manusia. Hal ini tersebut didasarkan pada tiga alasan, yakni: pertama, agama memiliki ikatan emosional atas nama keimanan yang berpegaruh sangat kuat terhadap perilaku sosial dan pembentukan kultur yang berlaku di masyarakat. Kedua, agama memiliki watak terbuka, sehingga agama selalu berusaha mengadaptasikan nilai dan eksistensinya terhadap sejarah. Ketiga, dalam proses adaptasi tidak jarang menghadirkan benturan antar agama dengan agama yang lain, sehingga hal tersebut membutuhkan bangunan toleransi yang kokoh. ${ }^{7}$ Dalam persoalan keberagamaan dan berkeyakinan yang menimbulkan perbedaan baik pada tingkat internal agama ataupun antar umat beragama, termasuk dalam Islam, dapat dipengaruhi oleh ragam ekspresi yang berbeda antara pemeluk agama atau intra beragama. Adanya ragam ekspresi kultural ini muncul sebagai sebab akibat yang logis dalam lingkungan sejarah dan geografis berbeda yang terbentuk selama berabad-abad, sehingga yang harus dijaga dari varian wajah ini tidak merusak bangunan tauhid dan kemanusiaan universal. ${ }^{8}$

\section{B. Metodologi Penelitian}

Penelitian ini menggunakan jenis penelitian lapangan (field research), sehingga penelitian ini dilakukan secara intensif, terperinci, dan mendalam terhadap objek yang diteliti, sebab secara lebih luas bahwa pendekatan pada akhirnya menentukan hasil yang diperoleh, sementara metodologi (process and procedure) akan mengikuti dan menyesuaikan dengan pendekatan yang akan digunakan oleh peneliti. ' Sumber data utama penelitian kualitatif ini menurut adalah katakata dan tindakan selebihnya adalah data tambahan. ${ }^{10}$ Jenis data yang digunakan adalah data primer dan data sekunder. Data primer adalah data yang didapatkan dari lapangan baik melalui observasi lapangan, wawacara dengan pihak yang berwenang. ${ }^{11}$ Untuk memberikan keterangan dan permasalahan yang diajukan pada saat penelitian dan wawancara dengan pengurus Forum Pemuda Kerukunan Umat Beragama Daerah Istimewa Yogyakarta (FPKUB DIY), Forum Kerukunan Umat Beragama (FKUB) dan unsur pemerintah yakni Kebanglinmas dan MUI DIY. Sedangkan data sekunder adalah data pendukung yang penulis manfaatkan adalah data dokumentasi dan arsip-arsip lainnya yang terkait dengan permasalahan yang penulis teliti. Sementara teknik pengumpulan data penelitian ini dilakukan dengan metode dokumentasi, observasi, wawancara dan kuesioner.

6 https://m.tempo.co/read/news/2016/03/23/058756291/kota-yogyakarta-masih-darurat-intoleransiberagama diakses 13/05/2016 waktu 19.16

7 Taufiqurrahman, Dinamika Toleransi Umat Beragama. Suara Merdeka, 20 Juni 2016. hlm. 4.

8 Ahmad Syafii Maarif, 1997, Islam Kekuatan Doktrin dan Kegamangan Umat, Pustaka Pelajar. Yogyakarta. Maarif. hlm. 25.

9 Amin Abdullah, dkk. 2006, Metodologi Penelitian Agama, Yogyakarta, LP UIN Suka, hlm. 10.

10 Lexy J. Moleong, 2001, Metode Penelitian Kualitatif, Bandung: PT. Remaja Rosdakarya. hlm.112.

11 Bambang Sunggono, 2007, Metodologi Penelitian Hukum. Jakarta: RajaGrafinfo Persada. hlm. 37. 


\section{Review Pustaka}

Hadirnya tindakan kekerasan yang mengatasnamakan agama atau aliran tertentu, harus mendapatkan perlakukan yang keras dihadapan hukum. Sebab tindakan kekerasan dalam agama apapun tidak pernah dibenarkan. Tindakan kekerasan cenderung mengenyampingkan jalan dialog dalam menghadapi dan menyelesaikan persoalan. Kemudian diperparah dengan mengenyampingkan dialog sehingga jalan kekerasan atas klaim kebenaran tertentu diekspresikan cara dan pemahaman sepihak, yang kadang ekspresi tersebut berujung jatuhnya korban dan kerusakan. Padahal, cara dialog dengan perbedaan dapat menjadi jalan menciptakan kedamaian, saling menghargai, toleransi dan sebagainya. Bentuk dialog menurut Ahmad Wahib disebut sebagai tindakan ofensif terhadap kelompok lain. Artinya, penganut agama tertentu atau kelompok tertentu harus mampu memahami dan berdialog secara bijaksana dan jujur dengan penganut atau kelompok lainnya sehingga mampu menghilangkan kecurigaan yang tidak perlu. ${ }^{12}$ Selain, bentuk dialog dan penguatan pemikiran inklusif perlu dijadikan ruang efektif dalam menyikapi perbedaan, tidak saja dalam bentuk pemahaman tetapi juga dalam tindakan kehidupan sehari-hari. Maka, untuk memberikan pemaknaan yang mengenai penelitian berbasis agama, maka adanya batasan penelitian pemaknaan agama dalam penelitian menjadi hal yang cukup penting untuk dilakukan. Namun, memandang pentingnya batasan makna agama dalam penelitian tersebut menurut Dudung Abdurrahman dengan meminjam pandangan Keith A. Robert, bahwa agama bisa dilihat dari tiga definisi, yakni, subtantif, fungsional, dan simbolik. ${ }^{13}$ Penelitian mengenai kerukunan umat beragama menjadi objek kajian menarik yang terus dieksplorasi oleh para peneliti dan akademisi. Sebab, kerukunan beragama sangat berkaitan erat dengan pemahaman, pemaknaan, kesadaran dan praktik mengenai ajaran sebuah agama yang dianut oleh seorang pemeluk agama. Apalagi, agama sebagai sebuah sistem kepercayaan dalam kehidupan umat manusia dapat dikaji dalam beberapa sudut pandang, tidak terkecuali pada agama Islam, khususnya yang berkembang selama lebih dari empat belas abad menyimpan banyak masalah yang harus diteliti, baik menyangkut masalah ajaran dan pemikiran maupun realitas sosial, politik, ekonomi, dan budaya yang bersumber dari ajaran agama tersebut ${ }^{14}$.

Penelitian yang berkaitan dengan kehidupan keberagamaan di DIY sudah pernah dilakukan oleh Tim Puslitbang Kehidupan Beragama dengan judul Dinamika Kehidupan Beragama Masyarakat di Yogyakarta. ${ }^{15}$ Objek penelitian ini dengan mengambil sampel terhadap beberapa perumahan di Yogyakarta, dimana nilai pluralisme dianggap lebih berkembang di daerah perumahan. Hasil penelitian ini menunjukkan bahwa perumahan berlatar belakang

12 Ahmad Wahib, 2012, Pergolakan Pemikiran Islam. Edisi Digital, Demokrasi Project Yayasan Abad Demokrasi, Jakarta, hlm. 63

13 Dudung Abdurrahman, Pendekatan Sejarah. Dalam Amin Abdullah, dkk., 2006, Metodologi Penelitian Agama, LP UIN Suka. Yogyakarta. hlm. 45, lihat juga Djamari, 1988, Agama dalam Perspektif Sosiologi, Jakarta: Dirjen Pendidikan Tinggi Departemen Pendidikan dan Kebudayaan, hlm. 15-17

14 Dudung Abdurrahman, Pendekatan Sejarah, Dalam Amin Abdullah, dkk., 2006, Metodologi Penelitian Agama, LP UIN Suka, Yogyakarta, hlm. 39

15 Tim Puslitbang Kehidupan Beragama, 2006, Dinamika Kehidupan Beragama Masyarakat di Yogyakarta. dalam: http://www.balitbangdiklat.kemenag.go.id/sinopsis-hasil-penelitian/kehidupan-beragama/223-dinamikakehidupan-beragama-masyarakat-yogyakarta.html diakses 10/7/2014 waktu 03.52 
agama Islam cenderung bersifat hiterogen, yakni terbagi klaster paham keagamaan menurut Muhammadiyah, NU dan Salafi banyak dipraktikkan, disebabkan paham keagamaan ini cukup banyak berkembang di Yogyakarta. Sedangkan kaum Nasrani cenderung tidak bisa terindifikasi, apakah Kristen atau Katolik. Tetapi kelompok Nasrani ini memiliki perkumpulan dengan nama Persekutuan Warga Nasrani Bukit Sion. Sehingga hasil penelitian menyebutkan terdapat enam terpeliharanya kehidupan bergama khususnya yang terjadi di Yogyakarta, yakni: kesamaan tempat tinggal, budaya Jawa, kesamaan politik, pendidikan, kepentingan ekonomi dan adanya rasa keamanan secara bersama.

Penelitian tentang kerukunan umat beragama di Yogyakarta dilakukan oleh Isa Farhani yakni Kerukunan Antar Umat Beragama di Yogyakarta ${ }^{16}$. Penelitian ini menunjukkan bahwa kondisi umat beragama di Yogyakarta cenderung lebih di bersifat dinamis, rukun dan hidup secara damai. Ada pun faktor kerukunan umat beragama tersebut meliputi: pemahaman dan pengamalan masing-masing agama, pelaksanaan pembinaan kerukunan umat beragama, adanya ketertiban dan keamanan dalam masyarakat yang kondusif, terjadinya kesepatan umat beragama dalam berbagai bidang, kondisi sosial yang stabil, serta faktor pendidikan yang melatarbelakanginya.

Penelitian lain meneliti berkaitan dengan peran Forum Kerukunan Umat Beragama (FKUB) dilakukan oleh A. Salim Ruhana dengan judul FKUB sebagai Forum Kerjasama Antarumat Beragama ${ }^{17}$ Penelitian ini membahas mengenai awal terbentuknya FKUB yang berawal dengan diterbitkannya Peraturan Bersama Menteri Agama dan Menteri Dalam Negeri (PBM) Nomor 9 dan 8 tahun 2006, sehingga FKUB terbentuk dari tingkat Provinsi dan Kabupaten/Kota. Penelitian ini cenderung melakukan ekpolorasi terhadap keberadaan dan peran FKUB secara keseluruhan, sehingga penjelasan mengenai peran dan tanggung jawab FKUB bukanlah hal yang mudah sebab hal ini erat dengan kesadaran untuk bekerjasama, berinteraksi dan berdialog mengenai masalah yang dihadapi dalam intra atau antar umat beragama.

Penelitian yang memotret kehidupan beragama dilakukan oleh Sabara dengan judul penelitian Potret Kerukunan Umat Beragama pada Masyarakat Multikultural (Studi Kerukunan Umat Beragama di Desa Banuroja Kabupaten Pohuwato Propinsi Gorontalo). ${ }^{18}$ Penelitian menunjukkan bahwa kerukunan antar umat beragama dan multikulturalisme pada masyarakat Desa Banuroja tidak saja ditunjukkan dalam bentuk toleransi dan koeksistensi pasif, tetapi juga ditunjukkan dalam bentuk kesetaraan seluruh elemen masyarakat ruang sosial, kebudayaan dan politik. Setidaknya, ada tiga faktor yang mendukung terciptanya kerukunan umat beragama di Desa Banuroja yakni rasa nasionalisme dan penerimaan terhadap kebinnekaan, peran tokoh masyarakat, dan pesantren Salafiyah Syafiiyah sebagai pilar kerukunan.

16 Isa Farhani, 2002, Kerukunan Antar Umat Beragama di Yogyakarta, Yogyakarta, IAIN Sunan Kalijaga, Skripsi, Tidak dipublikasikan.

17 A. Salim Ruhana, "FKUB sebagai Forum Kerjasama Antarumat Beragama" dalam Jurnal Harmoni, Vol. VIII. No. 30 (April-Juni 2009)

18 Sabara, "Potret Kerukunan Umat Beragama pada Masyarakat Multikultural (Studi Kerukunan Umat Beragama di Desa Banuroja Kabupaten Pohuwato Propinsi Gorontalo", Jurnal Al-Fikr, Volume 17, Nomor 3 Tahun 2013, hlm. 81-91 
Penelitian yang berkaitan dengan kerukunan umat beragama dilakukan oleh Puslitbang Kemenag RI dan sudah berbentuk buku. Buku hasil penelitian ini yakni Survei Nasional Kerukunan Umat Beragama di Indonesia. ${ }^{19}$ Penelitian yang bersifat kuantitatif ini menujukkan bahwa kerukunan keagamaan secara nasional dalam kondisi yang baik. Kondisi ini salah satunya dipengaruhi seragkaian peran pemerintah dalam membina kerukunan antar umat beragama, sekalipun secara sosiologis keadaan ini harus diposisikan secara dinamis yang tidak menutup kemungkinan ada perkembangan dan perubahan setiap saat. Dalam penelitian ini menggunakan instrumen angkat/kuesioner tertutup menggunakan skala Likert dengan lima pilihan jawaban. Sedangkan variabel dalam penelitian ini terdapat tiga variabel yang hendak diketahui peneliti yakni persepsi tentang kerukunan umat beragama, sikap dan interaksi antarumat beragama, dan kerjasama antarumat beragama. Sehingga hasil penelitian dalam buku ini menunjukkan bahwa kerukunan keagamaan secara nasional dalam kondisi yang baik.

Istilah kerukunan umat beragama berasal dari tiga kata yakni rukun, umat, dan agama. Rukun berasal dari bahasa Arab yakni ruknun artinya dasar atau asas-asas, sementara dalam abjektiva berarti baik atau damai, sehingga kerukunan berarti perihal hidup rukun atau rasa rukun. Umat berarti pemeluk dan pengikut sebuah agama. Agama adalah ajaran, tuntunan, atau pedoman hidup manusia yang berasal dari Tuhan melalui perantara para Nabi atau Rasul. ${ }^{20}$ Artinya, agama dalam pemaknaan yang lebih merupakan sistem, prinsip kepercayaan kepada Tuhan dengan ajaran dan kewajiban yang bertalian dengan kepercayaan tertentu. Sementara, kerukunan umat beragama sebagai bentuk interaksi para pemeluk agama yang satu dengan yang lain sangat dipengaruhi proses interaksi tersebut berlangsung. Maka, proses interaksi ini pada titik tertentu menimbulkan paham keagamaan lebih plural dan inklusif akibat proses interaksi dilakukan lintas pemeluk agama. Untuk memahami mengenai kerukunan umat beragama bila merujuk pada pengertian Peraturan Bersama Menteri Agama dan Menteri Dalam Negeri sebagai berikut:

keadaan hubungan sesama umat beragama yang dilandasi toleransi, saling pengertian, saling menghormati menghargai kesetaraan dalam pengamalan agamanya dan kerjasama dalam kehidupan bermasyarakat, berbangsa, dan bernegara di dalam Negara Kesatuan Republik Indonesia berdasarkan Pancasila dan Undang Undang Dasar Negara Republik Indonesia Tahun $1945^{21}$.

Agama adalah modal keyakinan yang memiliki sumber elan vital yang sangat besar makna dan pengaruhnya terhadap pembentukan pikiran dan sikap hidup manusia, dibandingkan sumber-sumber lain seperti, ekonomi dan politik. ${ }^{22}$ Maka, lahirnya paham keagamaan tidak bisa dipisahkan dari upaya manusia untuk menyesuaikan ajaran agama dengan perubahan

19 Haidlor Ali Ahmad (Ed.), 2013, Survei Nasional Kerukunan Umat Beragama di Indonesia, Jakarta, Litbang Kemenag RI.

20 Ahmad Syafi'i Mufid, "Faham Islam Transnasional dan Proses Demokratisasi di Indonesia”, Jurnal Harmoni. Volume VIII, Nomor 30, April-Juni 2009. hlm. 8.

21 Peraturan Bersama Menteri Agama dan Menteri Dalam Negeri Nomor 9 Tahun 2006/Nomor 8 Tahun 2006 Bab I Pasal 1 Ayat 1.

22 Syukri. “Agama dan Peradaban” Jurnal Harmoni. Volume VIII, Nomor 30, April-Juni 2009. Hlm. 9-25. 
lingkungan sosial dan budaya masyarakat. ${ }^{23}$ Oleh sebab itu, adanya paham keagamaan yang inklusif yang ditandai dengan penghargaaan dan penghormatan terhadap keyakinan di masyarakat menjadi hal yang sangat fundamental guna tercapainya kerukunan umat antar umat beragama. Kerukunan keberagama akan terlaksana dengan baik dikarenakan pula adanya peran dalam masing individu atau kelompok. Keberadaan peran ini dapat dipandang sebagai kontribusi, partisipasi dan kepedulian untuk saling berbagi, sehingga timbulnya peran yang integral diharapkan mampu melahirkan rasa tanggung jawab bersama. Barangkali, timbulnya peran aktif diikuti ajaran agama yang tidak cukup hanya dipahami secara abstrak mengenai kepercayaan dan nilai sebab agama menyatu dalam diri dan hidup nyata pemeluknya. ${ }^{24}$

Persoalan timbulnya ketidakrukunan atau kekerasan yang mengatasnamakan agama dapat terjadi melalui beragam faktor yang melatar belakangi. Biasanya, hal tersebut terjadi diakibatkan oleh persoalan mendasar yang terjadi para pemeluk agama diantaranya: pertama, adanya wawasan keagamaan yang sempit dan ekslusif. Kedua, penyalahgunaan simbol agama untuk melegitimasi tindakan kekerasan yang dilakukan. Ketiga, lingkungan yang tidak kondusif, terutama terkait dengan kemakmuran dan ketidakadilan. Keempat, adanya perlakuan yang tidak adil terhadap kelompok atau negara terhadap sebuah komunitas ${ }^{25}$. Maka, dengan memahami faktor mendasar tersebut diatas timbulnya ketidakrukunan dan kekerasan yang mengatasnamakan agama dapat diantipasi sedari awal, sehingga tidak menjadi konflik laten yang berlangsung lama di masyarakat. Berkaitan konflik bernuansa agama pada dasarnya dapat diketahui melalui akar konflik bernuansa agama seperti adanya klaim kebenaran, pengaruh pemimpin agama, upaya membangun jaman yang ideal, tujuan dengan penghalalan segala cara, serta perang suci $^{26}$. Maka, terjadinya konflik berlatarbelakang agama memiliki akar konflik tersendiri. Oleh sebab itu, bentuknya penyelesaiannya juga tidak bisa diseragamkan antara konflik yang satu dengan yang lainnya. Maka, adanya peran kelompok umat beragama bisa menjadi upaya yang paling mendasar meningkatkan pemahaman dan aktualisasi ajaran luhur agama menjadi lebih membumi dalam kehidupan sehari-sehari. Sebab agama yang dipelajari, diperbincangkan, diamalkan secara sungguh-sungguh akan menghadirkan kedamaian dan peradaban dikarenakan agama memiliki peranan penting dalam memberi arah dan arti bagi kehidupan umat manusia ${ }^{27}$.

Tiap dimensi kehidupan bermasyarakat diperlukan relasi integral yang menunjukkan partisipasi diri atau kelompok dengan sesama individu atau kelompok yang lain. Hal ini bisa dilakukan dengan cara saling memahami, menghargai dan mengerti berbagai persoalan yang menyangkut bersama, sesama anggota masyarakat. Oleh sebab itu, keberadaan peran masing-

23 Ahmad Syafii Mufid, "Paham Islam Transnasional dan Proses Demokratisasi di Indonesia," Jurnal Harmoni. Volume VIII, Nomor 30, April-Juni 2009. hlm. 8-34.

24 Nurcholish Madjid, 1992, Islam Doktrin Peradaban, Sebuah Telaah Kritis tentang Masalah Keimanan, Kemanusiaan dan Kemoderenan, Yayasan Wakaf Paramadina, Jakarta, hlm. 582

25 Yusdani, "Pengelolaan Konflik Umat Agama di Indoensia," Jurnal Millah, Volume XII, No. 2, Februari 2013. hlm. 621

26 Yusdani, "Pengelolaan Konflik Umat Agama di Indoensia," Jurnal Millah, Volume XII, No. 2, Februari 2013. hlm. 618-619.

27 Syukri, "Agama dan Peradaban” Jurnal Harmoni. hlm 10. 
masing individu ataupun kelompok sangat diperlukan. Dalam konteks ini, menurut Franz Magnis Suseno keagamaan yang sebenarnya tetap menjadi salah satu pengembangan budi luhur dan pendukung serta penunjang kuat perdamaian secara ampuh. ${ }^{28}$ Konflik berlatar agama terkadang muncul dari paradigma eksklusif dalam memahami ajaran agama, serta masih adanya pandangan dan pemahaman setiap pemeluk agama memandang dan menyakini bahwa doktrin agama yang diyakinilah yang paling unik, ekslusif, superior dan yang paling benar. ${ }^{29}$ Selain itu, konflik antar umat beragama terkadang disebabkan oleh cara-cara penyiaran agama tertentu yang kurang atau bahkan tidak menghiraukan etika agama dengan alasan ingin menambah para pengikut tanpa memperdulikan lingkungan sekitarnya. ${ }^{30}$ Paradigma hal tersebut itulah secara perlahan menyebabkan disintegrasi dalam kehidupan bermasyarakat dan mengabaikan ajaran agama yang menganjurkan agar para pemeluknya dapat membina, menjaga, mendorong kehidupan yang harmoni dan inklusif sesama pemeluk agama dan antar umat beragama di masyarakat. Sebab kehidupan bermasyarakat pada hakikatnya merupakan proses interaksi dan proses dialektika yang berlangsung lama dengan segala macam bentuk keunikan dan kekhasannya. Proses keunikan tersebut dapat terlihat dari interaksi berbagai pengikut agama yang satu dengan yang lain dapat hidup rukun dan damai secara berdampingan dengan segala bentuk perbedaan, ataukah harus hidup saling membenci dan memusuhi kelompok lain yang berbeda agama. ${ }^{31}$ implikasinya proses interaksi tersebut menjadi tolak ukur mengenai bagaimana pemeluk agama dapat memahami ajaran agama yang diyakininya, serta mampu mengamalkan dan memberikan dampak positif interaktif dalam kehidupan sosial kemasyarakatan.

Upaya membangun dan mendorong paradigma inklusif dalam konteks ajaran Islam salah satunya digelorakan oleh Alwi Shihab. Islam inklusif memahami bahwa perlu adanya dialog lintas pemahaman sesama internal umat islam sendiri, tetapi juga di luar umat Islam. Adanya gerakan Islam inklusif ini tidak bisa dihindari mengingat pola interaksi masyarakat khususnya umat Islam harus diharapkan dengan perkembangan masyarakat, perkembangan pengetahuan dan berbagai persoalan kemanusiaan lainnya yang menuntut adanya sudut pandang yang lebih lentuk dalam memahami dan memaknai ajaran agama, tanpa harus kehilangan identitas dan nilai-nilai fundamental sebuah agama, sehingga pada titik tertentu tidak perlu ada pemeluk agama yang menganggap diri sebagai pemeluk agama yang lebih superior atas pemeluk agama yang lain yang mengabaikan kebenaran universal ajaran agama. Artinya, adanya paradigma inklusif merupakan upaya dalam mendorong pemahaman dan sikap menerima perbedaan dan kemajemukan pada pemeluk dan komunitas intra dan antar umat beragama.

28 Ihsan Ali-Fauzi (Ed.), 2012, Demi Toleransi Demi Pluralisme Esai-Esai untuk Merayakan 65 Tahun M. Dawam Rahardjo, Jakarta, Demokrasi Project Yayasan Abad Demokrasi. hlm. 317-318

29 Alwi Shihab, 1998, Islam Inklusif Menuju Sikap Terbuka dalam Beragama, Bandung: Penerbit Mizan, Cetakan IV. hlm. 40

30 Maarif, Islam, hlm. 110

31 Nurcholis Madjid, dkk., 2004, Fiqh Lintas Agama: Membangun Masyarakat Inklusif-Pluralis, Jakarta, Paramadina, hlm. 63-64 


\section{Hasil dan Pembahasan}

Data hasil penelitian ini dimulai dengan menjelaskan sejarah berdirinya Forum Pemuda Kerukunan Umat Beragama Daerah Istimewa Yogyakarta (FPKUB DIY). Awal mula berdirinya FPKUB DIY dimulai dari sebuah kekhawatiran bersama dikalangan tokoh masyarakat yang berada di Forum Kerukunan Umat Beragama (FKUB) dan pemerintah Daerah Istimewa Yogyakarta (DIY) dalam menjaga keharmonisan DIY sebagai kota plural, disamping sebagai kota wisata dan pendidikan. Apalagi, DIY telah memiliki semboyan the city of tolerance yang merupakan daerah bertemuanya berbagai etnis, budaya, dan agama. Maka, pada tanggal 12 April 2012 pengurus FKUB DIY bersama Kesbanglinmas DIY mengundang organisasi kepemudaan yang ada di DIY. Alasan pemilihan organisasi kepemudaan tersebut agar memudahkan koordinasi dan mobilisasi kegiatan mengenai kerukunan beragama pada tingkat organisasi kepemudaan dan pemuda secara umum di DIY. Dalam kegiatan tersebut didiskusikan mengenai pentingnya kerukunan dan paradigma inklusif kalangan pemuda di DIY dengan mengeksplorasi peluang dan tantangan kaum muda dalam menjaga dan mendorong DIY sebagai the civil of tolerance. Selain itu, pada pertemuan tersebut dipaparkan mengenai kerangka organisasi pemuda kerukunan beragama yang kemudian ditindaklanjuti dengan adanya pertemuan tanggal $15 \mathrm{Mei}$ 2012 di Hotel LPP. Hasilnya dalam pertemuan tersebut para peserta yang hadir menyepakati nama organisasi tersebut bernama Forum Pemuda Kerukunan Umat Beragama (FPKUB) DIY. Pada proses pertemuan berikutnya yang dilaksanakan pada tanggal 24 Mei 2012 bertempat di Kantor Kesbanglinmas DIY diadakan diskusi mengenai formatur dan struktur pengurus forum yang berasal dari perwakilan masing-masing organisasi. Adapun para formatur tersebut sebagai berikut:

Tabel 1:

Formatur pendiri FPKUB DIY

\begin{tabular}{|c|l|l|}
\hline NO & \multicolumn{1}{|c|}{ Nama } & \multicolumn{1}{c|}{ Utusan } \\
\hline 1 & Andi Abbas & PI \\
\hline 2 & Danang Ari Wibowo & $\begin{array}{l}\text { Komisi Hubungan antar Agama dan } \\
\text { Kepercayaan Kevikepan DIY }\end{array}$ \\
\hline 3 & Faik Muhammad & Ponpes Al-Munawwir \\
\hline 4 & Fredi Oksana S. & Pemuda Muhammadiyah \\
\hline 5 & Giyanti & WALUBI DIY \\
\hline 6 & Hesti & Nasyiatul Aisyiyah \\
\hline 7 & I Gede Mas Saputra & PERADAH \\
\hline 8 & Ignatius Ganjar Tri H & Pemuda Katolik \\
\hline 9 & Imam S. Arizal & PMII Cabang DIY \\
\hline 10 & Ludikson Siringo Ringo & GAMKI \\
\hline
\end{tabular}




\begin{tabular}{|c|l|l|}
\hline 11 & Makhrus Ahmadi & DPD IMM DIY \\
\hline 12 & Hanum Hanifah & Kesbanglinmas DIY \\
\hline 13 & Slamet & GP Ansor DIY \\
\hline 14 & Sulasmi & IPPNU DIY \\
\hline 15 & Syaifuddin Al Ghazali & GP Ansor DIY \\
\hline 16 & $\begin{array}{l}\text { Wiwin Siti Aminah } \\
\text { Rohmawati }\end{array}$ & PW Fatayat NU DIY \\
\hline
\end{tabular}

Sumber : Berbas Kerangka Dasar FPKUB DIY

Tim formatur pun mengadakan rapat kembali dengan membentuk struktur kengurusan FPKUB DIY. Adapun hasil beberapa pertemuan tersebut yang kemudian telah ditembuskan kepada pengurus FKUB DIY dan Kesbanglinmas DIY. Prinsipnya keberadaan FKUB DIY sebagaimana tertuang dalam kerangka berdirinya forum tersebut menghendaki bentuk aktivitas dalam mewujudkan paradigma inklusif kaum muda dilakukan dengan tiga cara yakni, pertama, selalu upaya mengedepankan dialog dalam segala bentuk interaksi kehidupan beragama. Kedua, menolak adanya kekerasan dalam bentuk apapun, tidak terkecuali bentuk kekerasan yang mengatasnakaman agama tertentu. Ketiga, mendorong adanya sikap proaktif kaum muda dalam segala bentuk kegiatan kerukunan beragama, sehingga mampu mendorong pemahaman dan kesadaran kaum muda mengenai pentingnya kerukunan beragama dalam lingkungan dan organisasinya.

Keberadaan FPKUB DIY menurut Syaifuddin Al Ghazali sekalu ketua presidium bahwa keberadaan FPKUB atau FKUB dalam tugas dan fungsinya masih diasumsikan sama dengan pemadam kebakaran. Artinya, terkadang tindakan penyelesaian terhadap kekerasan dan konflik atas bernuansa agama dilakukan bila hal tersebut sudah terjadi, sehingga masih belum didorong untuk menciptakan keadaan yang kondusif dengan beragam program. Program kerja yang diagendakan FPKUB DIY disesuaikan dengan kebutuhan anggota forum dan kebutuhan kaum muda dalam mendorong paradigma inklusif dengan menjabarkan tiga prinsip FPKUB DIY diatas yakni, dialog, adanya kehidupan beragama yang nir kekerasan dan sikap proaktif kaum muda. Selain itu, keterlibatan semua stakeholders yang memiliki visi dan misi yang sama dalam mendorong kehidupan harmoni dan paradigma inklusif juga menjadi konsentrasi kegiatan yang dilaksanakan oleh FKUB DIY. Misalnya, keterlibatan FPKUB dalam kegiatan hari raya keagamaan, kemah keagamaan, kemah kebangsaan, dialog publik kebagamaan dan lainya. ${ }^{32}$

Realisasi program menjadi salah satu indikator penting dalam proses pelaksanaan rencana program tertuang dalam beberapa kegiatan yakni: pertama, dialog pemuda antar umat bergama, kegiatan ini merupakan kegiatan rutin yang dilaksanakan oleh FPKUB DIY dalam mendorong pemahaman dan kesadaran inklusif antar umat beragama di kalangan kaum muda di DIY. Awalnya, kegiatan ini dilaksanakan oleh anggota forum dengan cara mengeksplor 
berbagai persoalan dan solusi mengenai kerukunan intra dan antar umat beragama yang kemudian ditindaklanjuti dalam berbagai dialog yang dilaksanakan oleh anggota forum pada masing-masing organisasinya. Kedua, kemah pembauran. Kegiatan ini merupakan kegiatan Kesbalinmas/Kesbangpol DIY yang bertujuan menumbuhkan dan membangun semangat kebangsaan di kalangan pemuda. Ketiga, sosialisasi pemilih pemula. Program ini terselenggara dengan bekerjasama dengan Kemendagri, dimana FPKUB DIY mendelegasikan peserta yang masih menjadi pemilih pemula dalam kegiatan tersebut, sehingga harapannya dapat memberikan wawasan yang baik mengenai pemahaman pemilih yang cerdas, khususnya dalam Pilpres 2014 kemarin. Keempat, pelatihan pengawasan pemilu bagi ormas yang diselenggarakan oleh Badan Pengawas Pemilu (Bawaslu) yang memiliki output kegiatan pengawasan pemilu berbasis ormas. Kelima, Studi banding. Program ini terlaksana dengan bekerjasama dengan Forum Kerukunan Umat Beragama (FKUB) DIY dengan melaksanakan kunjungan ke Bali untuk mempelajari praktik kekurunan beragama yang dilaksanakan di pulau dewata tersebut ${ }^{33}$.

Berkaitan dengan kasus intoleransi yang menjadi bahan kajian FPKUB DIY diantaranya yakni: pertama, pendirian rumah ibadah yang berawal dari rumah pribadi sebagaimana terjadi Kabupaten Sleman. Hal ini berawal dari adanya rumah pribadi yang dijadikan rumah ibadah yang dilakukan secara rutin, awalnya tidak setiap hari tetapi lambat laun menjadi kegiatan rutin setiap hari sehingga menyebabkan penolakan dari masyarakat. Kedua, respon terhadap terhadap isu yang sedang berkembang di masyarakat sebagaimana terjadi pada kasus mengenai penutupan pondok waria di Bantul yang sebenarnya dipengaruhi oleh merebaknya isu Lesbian, Gay, Biseksual, dan Trangender (LGBT), sehingga peran dan aktivitas para waria menjadi sorotan oleh kelompok-kelompok tertentu. Ketiga, perbedaan sudut pandang antar individu atau kelompok terhadap ajaran dan persoalan kehidupan beragama. Hal ini terlihat dengan adanya adanya pembubaran terhadap diskusi dan bedah buku bersama Irshad Manji yang dilaksanakan di Kantor LKiS yang menyebabkan kerugiaan materiel. Keempat, timbulnya legalitas pendirian rumah ibadah secara sepihak. Kasus ini sebagaimana terjadi pada kasus Gua Maria di Gunung Kidul. Secara geografis keberadaan Gua Maria merupakan tempat sembahyang (beribadah) umat Nasrani, sementara dibawah gua tersebut terdapat langgar yang jaraknya sekitar 200 meter. Kasus lainnya juga terjadi pada kompleks pantai Ngobaran menjadi tiga tempat beribadah tiga agama yang berbeda yang sebenarnya berada dibawah kepemilikan Sultan Ground ${ }^{34}$.

Berdasarkan respon dari anggota forum yang pernah menerima program dan mengikuti kegiatan yang diselenggarakan oleh FPKUB DIY ditemukan respon yang berbeda antar sesama anggota forum. Respon tersebut terbagi atas dua bagian yakni: pertama, respon berkaitan dengan peran dan program yang dilaksanakan oleh FPKUB DIY. Kedua, respon berkaitan dengan evaluasi dan hasil pelaksanaan FPKUB DIY itu sendiri. Berdasarkan hasil respon tersebut menunjukkan bahwa peran dan program yang telah dilaksanakan oleh FPKUB DIY disambut positif oleh para peserta yang menerima program yang ditunjukkan dengan memandang baik peran yang dilakukan FPKUB DIY yang ditandai dengan jumlah 55\% peserta yang menyatakan setuju dan

33 Wawancara dengan Syaifuddin Al Ghazali 34 Wawancara dengan Syaifuddin Al Ghazali 
30 \% sangat setuju atas peran FPKUB DIY sudah baik dalam memperkuat paradigma inklusif kaum muda di DIY. Sementara berkaitan dengan muatan materi dalam beberapa program yang disampaikan dalam memperkuat paradigma inklusif kaum muda FPKUB DIY tidak hanya menambah skill, melainkan juga menambah motivasi, sikap, dan perilaku dalam membina kerukunan dan toleransi dalam bermasyarakat dengan respon setuju sampai $90 \%$.

Respon tokoh masyarakat terkait keberadaan dan peran FPKUB DIY dalam memperkuat paradigma inklusif kaum muda di Daerah Istimewa Yogyakarta sangat menyambut positif, bahkan keberadaan FPKUB DIY dijadikan proyek percontohan mengenai mengenai forum pemuda kerukunan umat beragama, sehingga harapannya dengan adnaya wadah bagi anak muda untuk saling berinteragsi mampu memberikan pikiran dan sikap membina kerukunan umat beragama tidak sacara lokal melainkan juga secara nasional ${ }^{35}$. Bila dipandang dari sudut pandang sejarah lahirnya FPKUB DIY tidak bisa dilepaskan dari peran aktif pada tokoh masyakat yang tergabung dalam FKUB DIY itu sendiri. Oleh sebab itu, dalam berbagai kegiatan yang dilakukan oleh FPKUB DIY hampir sama dengan yang dilakukan oleh FKUB DIY, hal yang membedakannya terletak pada objek dan proses kegiatan yang dilaksanakan yang diorientasikan pada kehidupan kaum muda. Upaya para tokoh masyarakat dalam membantu dan mendorong mengenai pentingnya paradigma inklusif dan sikap toleransi dan harmoni di kalangan kaum muda di DIY yakni memberikan perhatian dan dukungan yang lebih maksimal terhadap peran dan fungsi dari FPKUB DIY, sehingga harapannya dengan adanya beragam bentuk kegiatan yang dilaksanakan dapat memberikan dampak positif yang sistemik dalam kehidupan seharihari kehidupan bermasyarakat, berbangsa, dan bernegara ditengah perbedaan ras, suku, dan agama. Bentuk kegiatan yang dilaksanakan oleh FPKUB DIY tersebut diadakan dengan bentuk dialog menggenai hal-hal yang terkait dengan inter dan intra umat beragama, sehingga terjalin komunikasi dan relasi efektif dan harmoni. ${ }^{36}$ Kasus mengenai konflik intra umat beragama dapat terlihat dengan adanya bentuk provokasi yang mengataskan pihak lain sebagai kafir atau bahkan bukan bagian dari pemeluk sebuah agama tertentu. Konflik intra umat beragama senantiasa akan semakin membesar manakala kedua belah pihak yang berseteru enggan atau tidak bisa memahami dan menerima perbedaan pandangan sebagaimana juga terjadi pada konflik antar umat beragama. ${ }^{37}$

Adanya FPKUB DIY sebenarnya sangat dibutuhkan perannya dalam masyarakat, meski pemerintah belum memberikan payung hukum yang jelas, sehingga keberadaan FPKUB DIY belum mendapatkan fasilitas pendanaan khusus dari pemerintah. Maka, para pengurus FPKUB DIY dimasukkan kedalam kepengurusan FKUB DIY. ${ }^{38}$ Menurut Hanum Hanifah keberadaan FPKUB DIY sejak didirikan merupakan pilot project mengenai forum kerukunan umat

35 Wawancara dengan KH. Thoha Abdurrahman selaku Ketua Forum Kerukunan antarumat Beragama (FKUB) dan Ketua Majellis Ulama Indonesia (MUI) DIY pada tanggal 18 Juli 2016 di kantor Bank BPD Syariah DIY.

36 Wawancara dengan KH. Thoha Abdurrahman

37 Wawancara dengan KH. Thoha Abdurrahman

38 Wawancara dengan Hanum Hanifah, SH. Kepala Sub. Bidang Bina Ideologi Kesbangpol DIY (Dulu Kesbanglingmas) pada tanggal 19 Juli 2016 di Kantor Kesbangpol DIY 
beragama yang berbasis anak pemuda, sehingga harapannya dapat menjadi proyek percontohan, sekalipun kegiatannya masih dicangkokkan kepada FKUB DIY yang didasarkan peraturan dua Menteri, yakni Menteri Agama dan Menteri Dalam Negeri yang mengatur kerukunan umat beragama. ${ }^{39}$ Sementara pemerintah Daerah Istimewa Yogyakarta lebih bersifat memfasilitasi dan mengkoordinir komponen pemerintah dan masyarakat agar terjadi dinamika yang harmonis dan kondusif. Hal yan bisa dilakukan dengan memahami dan mengenai potensi konflik yang akan terjadi atau tindakan antisipatif melalui pemetaan dan basis data yang ada. Selain itu, diperlukan adanya counter terhadap berita yang tidak berimbang, khususnya media sosial yang menyebabkan adanya konflik horisontal sesama pemeluk agama. Sebab beberapa kasus mengenai kekerasan sebenarnya merupakan pidana murni kemudian dipandang sebagai kekerasan beragama, apalagi selama ini belum ada konflik beragama yang berbabasis agama di DIY dalam segala besar. Hal ini menandakan bahwa kehidupan beragama di DIY terbilang kondusif dan penuh dengan sikap toleran, sementara konflik atau kekerasan yang terjadi selama ini merupakan lebih bersifat kurangnya komunikasi dan interaksi yang menimbulkan kesalahpahaman di kalangan masyarakat. ${ }^{40}$

Kerukunan antar umat beragama menjadi isu dan permasalahan tersendiri yang harus menemukan beragama solusi yang komprehensif. Hal tersebut dikarenakan kerukunan antar umat beragama melibatkan beragam unsur, kultur, dan latar belakang yang serba berberda satu sama lain. Oleh sebab itu, terjadinya atau terlaksananya kerukunan antar umat beragama harus ditopang oleh visi dan orientasi yang dibungkus dalam koridor sikap toleransi yang kuat. Maka, hal yang paling mendasar untuk mewujudkan sikap toleransi tersebut adalah memperkuat dan memperkuat paradigma inklusif pada setiap individu dan kelompok bahwa ada sebuah keyakinan dan kepercayaan berbeda pada indivbidu dan kelompok lain yang harus diterima sebagai sebuah keniscayaan dalam kehidupan bermasyarakat. Adanya perbedaan keyakinan dan kepercayaan tersebut harus dipandang dalam sudut pandang sebagai sebuah pilihan yang tidak bisa dipaksakan dan diterima apa adanya. Sebab, setiap pemeluk agama atau kepercayaan selalu memiliki alasan tersendiri pada setiap individu atau kelompok. Apalagi, agama sebagai realitas sosial didalamnya tidak hanya terkandung ajaran yang bersifat normatif-doktrinal, tetapi juga meliputi variabel pemeluk, tafsir ajaran, lembaga keagamaan, tempat suci, dan hubungan ideologi yang dibangun dan dibela para pemeluknya ${ }^{41}$. Maka, adanya paradigma inklusif dan sikap toleransi menjadi hal yang tidak bisa ditawar atau bahkan menjadi keniscayaan yang harus diterima oleh semua pemeluk agama. hal tersebut diakibatkan karena adanya interaksi antar pemeluk agama yang mengakibatkan pola interaksi menjadi lebih kompleks daripada kehidupan masyarakat yang tidak mengalami pola interaksi masyarakat yang plural.

Adanya paradigma inkusif dan sikap toleran secara perlahan akan menyebabkan kultur dan perilaku masyarakat cenderung lebih harmonis. Sebab, pada keduanya terciptanya pemahaman, kesepakatan, dan budaya yang saling melengkapi ditengah perbedaaan pilihan kepercayaan

39 Wawancara dengan Hanum Hanifah

40 Wawancara dengan Hanum Hanifah

41 Nur Achmad (Ed.). 2001. Pluralitas Agama Kerukunan dalam Keragaman. Kompas. Jakarta. hlm. 88 
(agama). Maka, timbulkan konflik atau kekerasan yang mengatasnamakan agama diantisipasi sedari dini atau bahkan diadakan guna mengurangi korban dan kerugian atas konflik yang akan terjadi, apalagi terjadinya konflik berbasis agama dapat dilihat dengan dua hal yakni: pertama, adanya alasan yang dijadikan sebagai pembenar dari terjadinya gejolak konflik, dimana sumber konfliknya tidak selalu bersumber dari ruang lingkup keagamaan, tetapi juga dari dimensi sosial non-agam, hal tersebut direduksi dari ruang epitimologis yang bersifat imanen kepada wujud praksis watak primordial yang akhirnya menyebabkan konflik. Kedua, konflik beragama berfokus pada masa kalangan bawah yang pemahaman keagamaannya bersifat verbalis ${ }^{42}$. Biasanya, pada aspek kedua inilah tidak jarang menjadi konflik laten yang sulit diurai dan diselesaikan, hal tersebut dikarenakan pemeluk agama yang bersifat verbalis hanya memahami agama ritualistik dan formalistik sehingga cenderung mengabaikan yang ajaran agama yang subtantif.

Upaya yang dilakukan oleh FPKUB DIY dalam mendorong paradigma inklusif di kalangan kaum muda di DIY merupakan salah satu cara membuka dan memberikan ruang dalam memperbesar pola dialog intra dan antar umat beragama. Sebab, generasi muda yang akan menjalani kehidupan bermasyarakat yang serba plural di masa yang akan datang, sehingga timbulnya konflik berlatar belakang agama dapat diantipasi secara lebih dini. Selain itu, penghargaan atas kebebasan beragama menjadi pilihan yang tidak lagi menjadi hal yang harus dipertentangkan antar individu ataupun kelompok yang diakibatkan oleh perbedaan keyakinan yang dianut. Oleh sebab itu, prinsip kebebasan beragama harus menjadi patokan bagaimana interaksi antar umat beragama dapat dipahami dan dipraktikkan secara bersama-sama di lingkungan masyarakat yang plural. Prinsip kebebasan beragama tersebut menurut Nurcholish Madjid adalah kehormatan bagi manusia oleh Tuhan, dikarenakan Tuhan mengakui hak manusia untuk memilih sendiri jalan hidupnya, meski hal tersebut tidak perlu lagi ditegaskan bahwa semua pilihan beragama tersebut merupakan tanggung jawab sepenuhnya manusia itu sendiri ${ }^{43}$.

Adanya upaya mendorong paradigma inklusif yang dilakukan oleh FPKUB DIY tersebut diatas harus dilihat oleh faktor, yakni: pertama, terbangunnya pemahaman dan kesadaran bersama pada intra umat beragama dalam memahami ajaran agama yang dianut dan diyakininya. Sebab, konflik intra umat beragama dapat menjadi persoalan konflik laten dikarenakan perbedaanperbedaan yang sulit menemukan ruang dialog. Timbulnya konflik intra umat beragama dapat terjadi dikarenakan adanya perbedaan pandangan, pemahaman, dan pengamalan yang berbeda sesama pemeluk sebuah agama, dimana seorang pemeluk agama dapat melakukan tindakan kekerasan dan konflikyang disebabkan oleh perbedaan pandangan, pemahaman, dan pengalaman seperti yang yakini oleh dirinya. Tindakan ini biasanya memberikan lebel tertentu seperti pengkafiran, bukan bagian dari ajaran agama, dan sebagainya. Hal tersebut dapat terlihat pada adanya bentuk pembubaran diskusi yang menghadirkan Irshad Manji dan pengrusakan kantor LKiS, serta pembubaran pondok waria di Bantul. Kedua, terjalinnya sikap toleransi antar umat beragama yang ditandai dengan sikap dan peran aktif dalam kegiatan saling tolong menolong, saling menghargai, saling berpartisipasi dalam berbagai bentuk aktivitas kemasyarakatan,

42 Achmad, Pluralitas. hlm. 99-100.

43 Nurcholish Madjid, 2004, Pintu Pintu Menuju Tuhan, Jakarta: Paramadina, Cetakan VII, hlm. 219 
termasuk memberikan rasa aman dan nyaman dalam setiap pelaksanaan penyelenggaraaan kegiatan keagamaan. Sebab, bila tidak terjalin dan terciptanya kesadaran dan sikap toleransi ini menyebabkan relasi antar umat beragama tidak dapat berjalan aman dan damai. Hal tersebut dapat terlihat dengan adanya penolakan Paskah Adiyuswa di Gunung Kidul, pelarangan ijin pendirian GKI Pos Palagan, penyerangan umat Katholik di Sleman, dan lainnya.

Konflik intra dan antar umat beragama harus dilihat dari beragam faktor yang melatar belakanginya, sebab konflik selalu memiliki latar belakang atau akar masalah sebagai pemicu terjadinya sebuah konflik. Maka, menurut Yusdani dalam memandang dan menganalisis secara obyektif konflik berbasis agama di Indonesia sebagaimana ia review dari buku Bahrul Hayat selaku Sekjend Kementerian Agama RI dengan judul buku Mengelola Kemajemukan Umat Beragama yang diterbitkan pada tahun 2013, bahwa nuansa konflik bernuansa atau berlatar belakang agama di Indonesia terlihat dalam gambar berikut ${ }^{44}$ :

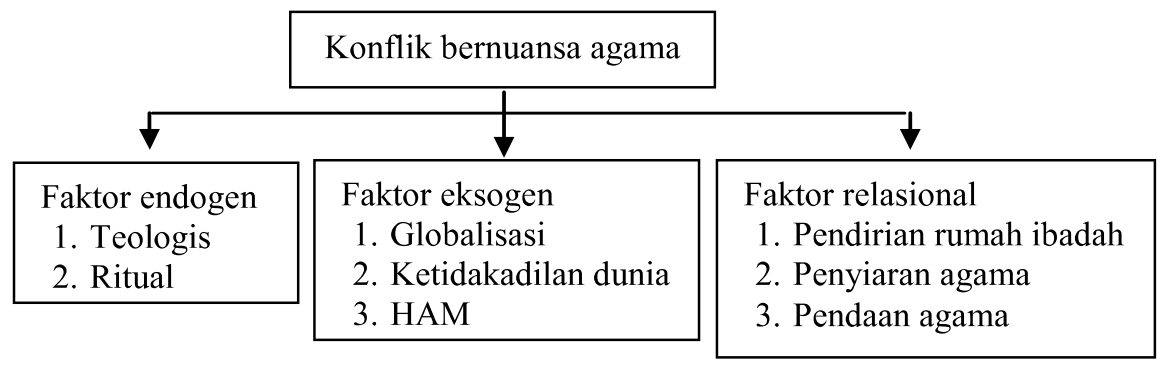

Gambar 1 :

Akar konflik bernuansa agama di Indonesia

Berdasarkan gambar diatas menunjukkan bahwa akar konflik bernuansa agama yang selama ini terjadi, termasuk di DIY memiliki faktor pemicunya tersendiri, sehingga para pelaku kekerasan/konflik tersebut memiliki alasan dan motif yang menyebabkan sebuah tindakan kekerasan/konflik tersebut bisa terjadi. Selanjutnya Yusdani menjelaskan bahwa pemetaan dan analisis konflik bernuansa agama harus mengintegrasikan tiga pendekatan sekaligus, yakni: pertama, cultural approach adalah pendekatan yang menekankan pada tradisi yang melekat dalam diri Islam Indonesia, sehingga dalam prosesnya pendekatan ini melihat interpretasi individu terhadap ayat-ayat suci serta dampaknya dalam mempengaruhi perilaku politik (political behavior). Dalam konteks beberapa karya ilmiah tentang radikalisme, pendekatan ini paling dominan digunakan dalam mempelajari Islam di Indonesia. Kedua, security approach merupakan suatu pendekatan yang banyak dilakukan oleh orang-orang yang tidak mengerti Islam, dimana para penganut pendekatan ini hanya mencomot dan mengkomparasikan beberapa pemikiran. Hal ini menyebabkan indikator yang tidak jelas mengenai konflik agama, bahkan pendekatan pertama dan kedua ini melahirkan perspektif good and bad moslem yang di Indonesia yang kemudian dikenal dengan istilah moderat dan radikal. Ketiga, historical sociology approach dan

44 Yusdani, "Pengelolaan Konflik Umat Agama di Indoensia," Jurnal Millah. Volume XII, No. 2, Februari 2013, hlm. 625 
political economy merupakan pendekatan yang bermuara pada kesimpulan bahwa ketidakadilan sosial sebagai akar dari konflik agama di Indonesia ${ }^{45}$.

Berdasarkan tiga pendekatan diatas, maka persoalan konfik bernuasa agama yang biasanya terjadi di Indonesia menurut Yusdani cenderung lebih banyak mengarah pada pendekatan ketiga, sebab ketidakadilan sosial dan semakin melebarnya disintegrasi dan relasi di masyarakat menjadi dapat salah satu pemicu konflik agama. Dalam konteks kekerasan bernuasa ketidakadilan sosial di DIY dapat terlihat dengan adanya penutupan paksa pesantren waria di Bantul, sebab hal tersebut bukan hanya persoalan ideologi, melainkan juga dipicu masih belum diterimanya kehidupan masyarakat trangender di lingkungan sosialnya. Oleh sebab itu, menurut Yusdani bahwa pembacaan terhadap ketidakadilan sosial ini setidaknya dilatarbelakangi oleh tiga faktor, yakni: pertama, ide ini merupakan respon terhadap globalisasi yang tidak bisa menepati janjinya untuk mensejahterakan rakyat. Kedua, karena tidak adanya organisasi lain (kiri) yang bisa menampung dan mewadahi pemikiran dan keinginan mereka. Ketiga, karena liberalisme telah didomestifikasikan ${ }^{46}$.

Berkaitan dengan pelaksanaan program, upaya yang dilakukan oleh FPKUB DIY dalam mendorong paradigma inklusif kaum muda DIY, ternyata memberikan dampak dan positif, hal tersebut dapat terlihat dari respon dari para yang pernah menerima program yang menunjukkan adanya perubahan pola pikir, sikap, dan perilaku mengenai pentingnya paradigma inklusif dan toleransi antar umat beragama. Dalam konteks kehidupan umat Islam upaya ini dapat dipahami sebagai pola hubungan ukhuwah islamiyah yang dalam pandangan Norcholish Madjib bahwa petunjuk memelihara persaudaraan Islam (ukhuwah islamiyah) adalah pertama, sikap saling terbuka dengan berapa pun besarnya perbedaan sekunder dalam paham dan tingkah laku. Kedua, jangan terlalu banyak prasangka karena mengakibatkan dosa (kejahatan). Ketiga, jangan menjadi mata-mata antar sesama. Keempat, jangan saling mengumpat dengan membicarkan keburukan orang lain ${ }^{47}$. Bila merujuk pada pandangan Norcholish Madjid diatas, maka relasi kehidupan intra dan antar umat beragama dengan memaksimalkan pemahaman dan praktik yang mendalam mengenai ukhuwah islamiyah akan menjadi salah dinamika praktik kehidupan masyarakat yang unik. Sebab, ajaran universalitas agama diletakkan pada posisi yang tanpa saling mencurigai, merasa paling benar, dan mencari kelemahan pihak lain yang berbeda pemahaman dan keyakinan. Sehingga terkait masalah agama atau kehidupan umat beragama Joachim Wach memandang perlu adanya beberapa unsur yang harus diperhatikan yakni: pertama, unsur teoritis yakni agama sebagai sistem kepercayaan yang melingkupi seluruh dimensi kehidupan manusia (penganutnya). Kedua, unsur praktis yakni berupa sistem kaidah yang mengikat para pemeluknya yang menjadi tatanan praksis kehidupan para pemeluknya. Ketiga, unsur sosiologi yakni agama mempunyai sistem hubungan dan interaksi sosial. Sehingga, implikasinya menurut Joachim Wach untuk menjelaskan bahwa jika salah satu unsur tersebut diatas tidak

45 Yusdani, "Pengelolaan Konflik Umat Agama di Indoensia," Jurnal Millah. Volume XII, No. 2, Februari 2013, hlm. 625-626

46 Yusdani, "Pengelolaan Konflik Umat Agama di Indoensia," Jurnal Millah. Volume XII, No. 2, Februari 2013, hlm. 626

47 Madjid, Pintu, hlm. 239-240. 
terdapat didalamnya, maka seseorang tidak dapat berbicara tentang agama, melainkan hanyalah kecenderungan religius ${ }^{48}$. Adanya kecenderungan-kecenderungan religius inilah terkadang menyebabkan sesama atau antar pemeluk agama mengalami konflik atau tindakan kekerasan, hal tersebut dikarenakan adanya pandangan yang menganggap diri paling benar atas apa yang diyakini atau merasa paling benar dengan apa yang dipahaminya.

Adanya respon positif terhadap kegiatan yang dilakukan oleh FPKUB DIY akan menciptakan citra positif, disamping citra negatif yang akan memberikan dampak kurang baik terhadap forum. Namun, hal tersebut dapat dilakukan dengan memaksimalkan berbagai peran strategis yang dapat menimbulkan pemahaman dan penerimaan masyarakat peran dan fungsi FPKUB DIY. Maka, upaya FPKUB DIY dalam mendorong paradigma inklusif kaum muda sehingga terwujud kehidupan harmoni yang menurut Imam Tholkhah dapat ditinjau dari pendekatan organisme. Pendekatan ini memberikan gambaran bahwa kehidupan beragama di Indonesia kadangkala mengalami kejadian fluktuatif, terkadang mengalami kondisi sehat, terkadang pula mengalami kondisi sakit dan sekarat. Kehidupan beragama yang sehat dapat terlihat dengan adanya persepsi, sikap, dan kerjasama yang membaik. Selain itu, upaya untuk menjadi hal tersebut tetap selalu dalam keadaan sehat dengan memberikan persepsi positif antar umat beragama sebagai anti body faham keagamaan. Sementara kehidupan beragama yang sedang dalam keadaan yang sakit ditandai dengan adanya virus sosial yang berakibat pada tindakan intoleran, radikal, provokator, dan sebagainya ${ }^{49}$.

Hubungan umat beragama dengan negara secara historis keduanya terkadang mengalami pasang surut di berbagai belahan dunia. Ada negara yang menjadikan agama sebagai alasan agama, sementara disisi lain ada pula negara yang sama sekali mengambil jarak dengan agama. Dalam konteks antara negara dan agama dalam hal ini adalah agama Islam, menurut Bahtiar Effendi hubungan Islam dengan negara bahwa Islam dipahami sebagai agama yang kekal dan universal, maka pemahaman kaum muslim terhadap terhadapnya tidak hanya sekadar pada pengertian formal dan legalnya, melainkan didasarkan pada penafsiran yang menyeluruh yang menerapkan petunjuk tekstual dan doktrinalnya pada kehidupan kontemporer ${ }^{50}$. Sehingga agama dapat dipandang sebagai instrumen Ilahiah untuk memahami dunia bahwa sebagian pemeluknya memandang dan meyakini bahwa Islam mencakup cara hidup yang total termasuk dalam kehidupan sosial, ekonomi dan politik pada ajaran yang ekslusif, tanpa menyadari kendala yang dihadapi yang muncul pada level praksisnya ${ }^{51}$. Hal ini sebenarnya, tidak hanya terjadi pada Islam dan pemeluknya, melainkan juga terjadi para agama dan pemeluk agama diluar Islam. Keberadaan negara menjadi sangat penting dalam setiap dinamika kehidupan umat beragama, sebab keberadaan negara semacam menjadi wasit ditengah beragam perbedaan keyakinan,

48 Dudung Abdurrahman, Pendekatan Sejarah, dalam Amin Abdullah, dkk. 2006, Metodologi Penelitian Agama. LP UIN Suka. Yogyakarta. hlm. 46.

49 Haidlor Ali Ahmad. Survei Nasional. Hlm. xviii-xix

50 Bahtiar Effendy, 1998, Islam dan Negara Transformasi Pemikiran dan Praktik Politik Islam di Indonesia, Jakarta: Paramadina, hlm. 134

51 Bahtiar Effendy, 1998, Islam dan Negara Transformasi Pemikiran dan Praktik Politik Islam di Indonesia, Jakarta: Paramadina, hlm. 7-8. 
kepercayaan, dan ideologi. Oleh sebab itu, dalam konteks yang lebih makro keberadaan negara harusnya berperan lebih dalam dialog bukan pemberian lebel dengan kata-kata sesat yang tidak menyelesaikan inti permasalahan. Maka, adanya peran negara sebagai komunikator harus memiliki peran lebih dalam membangun dan memperbesar berbagai dialog keagamaan yang terkadang mengalami kebuntuan menemukan solusi yang akhirnya menyebabkan konflik laten di masyarakat. Upaya komunikator yang dilakukan oleh negara dapat dilakukan dengan memperkuat kesadaran masyarakat tehadap nilai kehidupan berbangsa dan bernegara. konstitusi, demokrasi, kebhinnekaan, hak asasi manusia, kesejahteraan sosial, transformasi nilainilai ketuhanan. Sementara itu, demokrasi, diversivitas, dan inklusifitas senantiasa akan menjadi energi nilai spiritual yang kuat dan mampu meredam benih-benih perpecahan dan perselisihan ${ }^{52}$.

Hadirnya forum, organisasi, dan kemunitas yang memiliki visi dan misi mengenai paradigma inklusif dan kerukunan antar umat beragama harus diberikan dukungan oleh semua pihak, sebab persoalan kerukunan umat beragama bukan hanya domain salah satu kelompok saja. Oleh sebab itu, diperlukan berbagai tindakan praksis yang mampu dilaksanakan secara bersama-sama, baik dalam skala kecil atau besar (gerakan) dalam jangka pendek maupun jangka panjang dengan segala bentuk macam kendalanya. Bila merujuk pada pandangan Ulil Abshar Abdalla ada tujuh kendala praksis yang dialog antar umat beragama. Pertama, elitis, hal ini terjadi menakala pada tingkat elit seringkali mengganggap pertemuan/dialog seolah mempengaruhi tindakan orang awam yang menjadi pengikut kelompok elitis tersebut. Kedua, tidak militan, hal ini dikarenakan terjadinya masih kurang agresinya para aktivis dalam mendorong dan memperjuangkan isu mengenai kerukunan beragama. Ketiga, jalur eceran yang ditandai oleh masih banyaknya para pendakwah yang kurang memahami mengenai pentingnya dialog antar umat beragama. Keempat, infrasukstur, hal ini ditandai dengan masih terbatasnya akses kelembagaan sebagai penunjang dialog antar umat beragama. Kelima, masih adanya prasangka, baik dikalangan aktivis pluralis terhadap aktivis konservatif dan begitu pula sebaliknya. Keenam, masih adanya ketidakadilan yang terjadi di masyarakat, bahkan dialog antar umat beragama dijadikan alat politik untuk menutupi ketidakadilan yang terjadi. Ketujuh, perlu adanya dialog internal antar kelompok bergama yang kemudian dapat berimbas terhadap dialog eksternal atau antar umat beragama ${ }^{53}$.

Keberadaan forum, organisasi, dan komunitas kerukunan umat beragama selalu memiliki tantangan tersendiri termasuk pada FPKUB DIY. Apalagi, pada umumnya tantangan utama kerukunan beragama menurut Musdah Mulia terbagi atas lima hal, yakni: pertama, umumnya umat beragama memandang dan menyakini bahwa ajaran agama adalah hukum Tuhan yang tidak dapat berubah. Kedua, umumnya umat beragama masih berpandangan konservatif dalam beragama sehingga sulit menerima ide pluralisme. Ketiga, umumnya umat beragama meyakini perbedaan status dan posisi antara laki-laki dan perempuan. Keempat, umumnya umat beragama masih meyakini bahwa yang berhak berbicara masalah agama adalah kaum laki-laki. Kelima,

52 Amin Abdullah “Transformasi Nilai Ketuhanan” Makalah dalam Pengajian Ramadhan 1437 H Pimpinan Pusat Muhammadiyah tanggal 10 Juni 2016 di Universitas Muhammadiyah Yogyakarta.

53 Achmad, Pluralitas. hlm. 176-180. 
umumnya umat beragama takut berbicara agama di ruang publik, khususnya isu kontroversial dan melawan pendapat mayoritas seperti isu politik, gender, seksualitas, dan lainnya, sehingga terkadang para cendekiawan dan tokoh agama lebih memilih diam karena takut disebut liberal atau anti agama ${ }^{54}$. Sementara itu, tantangan spesifik yang dihadapi oleh FPKUB DIY adalah terus meningkatkan peran, program, dan eksistensi yang masih terkendala payung hukum kelembagaan.

\section{E. Kesimpulan dan Rekomendasi}

Keberadaaan FKUB DIY sebagai forum yang memiliki konsentrasi gerakan dalam memperkuat paradigma inklusif dan kerukunan umat beragama kaum muda DIY sebagaimana menjadi objek dalam penelitian ini memiliki kesimpulan sebagai berikut:

1. Peran FPKUB DIY dalam memperkuat paradigma inklusif kaum muda di Daerah Istimewa Yogyakarta dilakukan dengan memperbanyak dialog keagamaan dan kebangsaan. Bentuk dialog ini dilakukan dengan membahas topik tertentu yang terkait dengan kerukunan intra dan antar umat beragama yang termasuk didalamnya upaya memperkuat kesadaran berbangsa dan bernegara. Bentuk program kegiatan yang dilaksanakan oleh FPKUB DIY tersebut terbagi atas dua bentuk kegiatan yakni: Pertama, dialog yang diselenggarakan oleh FPKUB DIY sendiri dengan melibatkan para anggota forum. Kedua, dialog yang dilaksanakan dengan sindikasi program dengan program mitra seperti Kesbangpol (Kesbanglinmas) DIY dan lainnya.

2. Respon tokoh masyarakat terkait peran FPKUB dalam memperkuat paradigma inklusif kaum muda di Daerah Istimewa Yogyakarta (DIY) salah satunya dilakukan dengan memasukkan perwakilan FPKUB DIY kedalam kepengurusan FKUB DIY yang menjadi forum tertinggi forum kerukunan antar umat beragama yang sudah ada disetiap Kabupaten dan Kota di DIY. Selain itu, secara historis lahirnya FPKUB DIY merupakan inisiatif para tokoh masyarakat guna mendorong adanya kesadaran bersama di kalangan anak muda mengenai kerukunan beragama berbasis anak muda, sehingga harapannya keberadaan FPKUB DIY menjadi program percontohan daerah lain di Indonesia mengenai forum kerukunan antar umat beragama berbasis kaum muda. Selain itu, respon para tokoh masyarakat ini juga dilakukan dengan menambantu adanya sindikasi program kerukunan umat beragama dengan forum lain dan masyarakat, sehingga program dan gerakan yang dilakukan oleh FPKUB DIY dapat tersosialisasi dengan baik.

3. Peran pemerintah Daerah Istimewa Yogyakarta dalam memperkuat paradigma inklusif kaum muda yang dilakukan oleh FPKUB DIY dilakukan dengan menyediakan sarana dan prasana untuk digunakan dalam berbagai kegiatan oleh FPKUB DIY, sekalipun terkait bentuk penyediaan fasilitas atas hibah dan program pendanaan belum bisa dilaksanakan dikarenakan belum adanya payung hukum yang menaungi keberadaan FPKUB DIY sebab tidak diatur dalam peraturan dua Menteri antara Menteri Agama dan Menteri Dalam Negeri. Pemerin-

54 Musdah Mulia "Memastikan Pluralisme di Indonesia" makalah dalam Internasional Strategic Dialoge "Media Reporting an Religious Intolerance" Jakarta,16-18 Maret 2012. 
tah daerah DIY membantu adanya sindikasi program dengan berbagai instansi pemerintahan yang memiliki program kerukunan umat beragama dan wawasan kebangsaan, sehingga FPKUB DIY dilibatkan dalam kemah pembauran yang dilakukan secara rutin oleh Kesbangpol DIY. Selain itu, pemerintah DIY juga mendukung upaya dilakukan oleh FPKUB DIY untuk menjadikan forum kerukunan beragama berbasis agama menjadi bagian forum atau organisasi yang nantinya juga dinaungi oleh Kemenpora agar upaya mendorong dan meningkat paradigma inklusif dan kekurukunan beragama di kalangan kaum muda dapat berjalan secara efektif.

Rekomndasi yang dapat ditinjaklanjuti melalui hasil penelitian ini, baik oleh pemangku kebijakan, masyarakat dan penelitian berikutnya adalah sebagai berikut:

1. Untuk pembuat kebijakan yang dalam hal ini pemerintah agar memberikan perlindungan regulatif terhadap forum kerukunan umat beragama berbasis kaum muda sehingga menjadi payung hukum atas segala bentuk aktivitas program, penerimaan hibah pendanaan dan lainnya. Selain itu, hal yang tidak kalah penting akan membantu upaya kerukunan intra dan antar umat beragama dapat dibangun dan direncanakan sejak dini.

2. Untuk objek penelitian ini yakni Forum Pemuda Kerukunan Umat Beragama Daerah Istimewa Yogyakarta (FPKUB DIY) supaya semakin lebih kreatif dalam mendorong dialog dan kesadaran paradigma inklusif dan kerukunan intra dan antar umat beragama, sehingga adanya upaya kreatif ini akan senantiasa meningkatkan partisipasi anak muda yang terlibat dalam berbagai program yang akan dilaksanakan FPKUB DIY, sehingga tidak hanya terbatas pada anggota forum saja.

3. Untuk tokoh masyarakat, hal ini dapat dilakukan dengan mendorong dan ikut berpartipasi dalam berbagai aktivitas membangun kerukunan intra dan antar umat beragama, khususnya yang dilakukan oleh anak-anak muda, sehingga radius gerakannya akan menyentuh seluruh lapisan masyarakat.

4. Untuk peneliti selanjutnya agar memperbanyak sumber data dan terlibat aktif sebagai pegiat dalam salah satu forum kerukunan umat beragama khususnya diluar Daerah Istimewa Yogyakarta, sehingga dapat lebih mendalam dalam mengeksplor berbagai solusi terhadap permasalahan yang hendak diteliti.

\section{BIBLIOGRAFI}

Abdullah, Amin, 1996, Studi Agama; Normativitas atau Historisitas? Yogyakarta: Pustaka Pelajar. dkk., 2006, Metodologi Penelitian Agama, Yogyakarta, LP UIN Suka. 
“Transformasi Nilai Ketuhanan” Makalah dalam Pengajian Ramadhan 1437 H Pimpinan Pusat Muhammadiyah tanggal 10 Juni 2016 di Universitas Muhammadiyah Yogyakarta.

Abdurrahman, Moeslim, 2005, Islam Yang Memihak, Yogyakarta: LKiS.

Achmad, Nur, (Ed.), 2001, Pluralitas Agama Kerukunan dalam Keragaman, Jakarta: Kompas.

Ahmad, Haidlor Ali, (Ed.), 2013, Survei Nasional Kerukunan Umat Beragama di Indonesia. Jakarta. Litbang Kemenag RI.

Effendy, Bahtiar, 1998, Islam dan Negara Transformasi Pemikiran dan Praktik Politik Islam di Indonesia, Jakarta: Paramadina.

Farhani, Isa, 2002, Kerukunan Antar Umat Beragama di Yogyakarta, Yogyakarta, IAIN Sunan Kalijaga, Skripsi, Tidak dipublikasikan.

Fauzi, Ihsan Ali, (Ed.), 2012, Demi Toleransi Demi Pluralisme Esai-Esai untuk Merayakan 65 Tahun M. Dawam Rahardjo, Jakarta: Demokrasi Project Yayasan Abad Demokrasi.

Hayat, Bahrul, 2012, Mengelola kemajemukan umat beragama, Jakarta: Saadah Cipta Mandiri.

Hidayat, Nurkholis, Isnur, Muhamad, Yonista, Febi, 2011, Peradilan Kasus Kasus Kebebasan Beragama dan Berkeyakinan Rangkuman 8 Studi Kasus: Dampak, Capaian, Hambatan dan Strategi, Jakarta: LBH Jakarta.

Jurnal Harmoni, Vol. VIII. No. 30 (April-Juni 2009).

Jurnal Millah, Volume XII, No. 2, Februari 2013.

Kerangka Kerja Forum Pemuda Kerukunan Umat Beragama 2013.

Maarif, Ahmad Syafii, 1997, Islam Kekuatan Doktrin dan Kegamangan Umat, Yogyakarta: Pustaka Pelajar.

Madjid, Nurcholish, 1992, Islam Doktrin Peradaban, Sebuah Telaah Kritis tentang Masalah Keimanan, Kemanusiaan dan Kemoderenan, Jakarta: Yayasan Wakaf Paramadina. dkk., 2004, Fiqh Lintas Agama: Membangun Masyarakat Inklusif-Pluralis, Jakarta, Paramadina. 2004, Pintu Pintu Menuju Tuhan, Cetakan VII, Paramadina, Jakarta.

Moleong, Lexy J., 2001, Metode Penelitian Kualitatif, Bandung: PT. Remaja Rosdakarya.

Mufid, Ahmad Syafii, "Paham Islam Transnasional dan Proses Demokratisasi di Indonesia" Jurnal Harmoni, Volume VIII, Nomor 30, April-Juni 2009.

Muhaimin AG (Ed.), 2004, Damai di Dunia, Damai untuk Semua: Perspektif Berbagai Agama, Jakarta: Puslitbang Depag RI.

Mulia, Musdah, "Memastikan Pluralisme di Indonesia” makalah dalam internasional Strategic 
Dialoge "Media Reporting an Religious Intolerance” Jakarta: 16-18 Maret 2012.

Sabara, "Potret Kerukunan Umat Beragama pada Masyarakat Multikultural (Studi Kerukunan Umat Beragama di Desa Banuroja Kabupaten Pohuwato Propinsi Gorontalo”. Jurnal Al-Fikr, Volume 17, Nomor 3 Tahun 2013.

Shihab, Alwi, 1998, Islam Inklusif Menuju Sikap Terbuka dalam Beragama. Bandung: Penerbit Mizan, Cetakan IV.

Sunggono, Bambang, 2007, Metodologi Penelitian Hukum, Jakarta: RajaGrafinfo Persada.

Suseno, Franz Magnis SJ., “Agama, Budi Luhur dan Perdamaian,” dalam Ihsan Ali-Fauzi (Ed.). 2012, Demi Toleransi Demi Pluralisme Esai-Esai untuk Merayakan 65 Tahun M. Dawam Rahardjo, Jakarta: Demokrasi Project Yayasan Abad Demokrasi.

Tim Puslitbang Kehidupan Beragama, 2006, Dinamika Kehidupan Beragama Masyarakat di Yogyakarta, dalam: http://www.balitbangdiklat.kemenag.go.id/sinopsis-hasilpenelitian/kehidupan-beragama/223-dinamika-kehidupan-beragama-masyarakatyogyakarta.html, diakses 10/7/2014 waktu 03.52 .

Taufiqurrahman, Dinamika Toleransi Umat Beragama, Suara Merdeka, 20 Juni 2016.

Wahib, Ahmad, 2012, Pergolakan Pemikiran Islam, Edisi Digital, Jakarta, Demokrasi Project Yayasan Abad Demokrasi.

Yonesta, Febi, dkk. 2012, Memupuk Harmoni Membangun Kesetaraan Inisiatif Paralegal LBH Jakarta dalam monitoring Praktik Intoleransi dan Diskriminasi Berbasis Agama di Wilayah Jabodetabek, Jakarta: LBH Jakarta.

Peraturan Bersama Menteri Agama dan Menteri Dalam Negeri Nomor 9 Tahun 2006/Nomor 8 Tahun 2006. 
